\title{
Eksistensi perpustakaan sebelum kehadiran Islam
}

\section{Sahidi}

\begin{abstract}
The library before Islam experienced a fairly dynamic development. This can be seen from the existing library in the Mesopotamian region which was originally a Sumaria as the originator of writing, until the library Telloh that developed where there are 30 thousand midrib or writing media there are also there. In that place also found some places used to memorize and there are books about religion, magic and legislation. History records that there were a number of libraries ever established by humans before the arrival of Islam in Arab and medieval Europe, this library is the Library in Mesopotamia, the Ancient Egyptian Library, the Ancient Greek Library, the Ancient Roman Library and the Library in Europe.
\end{abstract}

Keywords: library, islam

\section{Pendahuluan}

Perkembangan perpustakaan tidak dapat dipisahkan dari sejarah manusia, karena perpustakaan merupakan produk manusia. Dalam sejarahnya, manusia mula-mula tidak menetap tetapi mengembara dari satu tempat ke tempat lain. Kehidupan seperti sering disebut kehidupan modern. Sejarah perkembangan perpustakaan telah dimulai jauh sebelum Masehi. Perkembangan perpustakaan diwarnai dengan perkembangan peradaban dan kebudayaan manusia itu sendiri (Nurhadi, 1983: 15).

Perpustakaan yang kita kenal seperti sekarang ini adalah lebih tua daripada kertas, buku dan mesin cetak. Sebab perpustakaan telah ada jauh sebelum benda-benda tersebut ditemukan orang. Perkembangan perpustakaan diperkirakan diawali dengan berkembangnya budaya dan pengenalan bentuk huruf-huruf sebagai formulasi suara atau bahan komunikasi. Huruf-huruf tersebut kemudian dirangkai menjadi kata-kata yang mengandung arti tertentu. Sementara kata-kata dirangkai menjadi kalimat, kalimat yang sempurna disusun menjadi alinea, tulisan 
baik berupa artikel, kumpulan tulisan naskah, deskripsi maupun buku sebagai formulasi yang lengkap. Pada awal mulanya koleksi perpustakaan terdiri dari tulisan-tulisan pada papirus, perkamen, daun lontar, tablet tanah liat, gulungan-gulungan tulisan dan benda-benda lain.

Dari segi lain, tanda ataupun tulisan yang dipahatkan pada pohon atau batu atau benda lain dapat digunakan sebagai catuman (record) megenai apa yang dikatakan mananusia maupun apa yang perlu diketahui seseorang. Adanya tulisan tersebut dapat membantu daya ingat manusia kini manusia dapat melihat "catatannya" ada pohon, batu, dan lempengan. Pesan dalam berbagai pahatan tersebut dapat diteruskan ke generasi berikutnya. Berbagai macam tulisan itulah yang dikumpulkan, disimpan, dan dipergunakan oleh masyarakat sebagai sumber ilmu pengetahuan dan informasi bagi masyarakat. Hal tersebut kemudian berproses dan berkembang secara bertahap sesuai dengan perkembangan kebudayaan manusia yang kemudian perkembangan perpustakaan dapat kita lihat dan digunakan seperti sekarang ini. Dengan melihat perkembangan perpustakaan dapat dikatakan bahwa perpustakaan menjadi rantai masa lalu, pijakan bagi kehidupan manusia di masa sekarang dan merupakan pembimbing untuk melangkah ke masa depan (Sutarno NS, 2006: 13).

Keberadaan perpustakaan dan kepustakaan sudah ada sejak zaman sebelum islam datang. Hal ini sudah dibuktikan oleh para ahli mengenai keberadaannya dengan bukti-bukti tulisan karya-karya yang dihasilkan oleh para ilmuan pada masa itu dan diiringi pula dengan perkembangan metode tulis menulis dan media cetak. Pada kesempatan ini penulis akan membahas tentang keberadaan perpustakaan sebelum islam yang banyak memberikan pengaruh terhadap peradapan manusia pada masa lampau dan pada masa sekarang yang dapat dilihat dari 
kemajuan-kemajauan bangsa Eropa di abad pertengahan hingga modern.

\section{Pembahasan}

\section{a. Sejarah Kepustakaan dan Perpustakaan Sebelum Islam}

Sejarah kepustakaan dan perpustakaan sebelum islam tidak jelas dalam keilmuan perpustakaan. Akan tetapi sangat penting untuk mengingat dan mengulas ulang sejarah ini dengan panjang lebar, karena sejarah ini dimulai bersamaan dengan peradaban manusia yang selalu dinamis. Sulitnya untuk menentukan sejarah kepustakaan dan perpustakaan pada masa lampau karena kurang jelasnya waktu dan tempat secara kronologis.

Sejarah awal kepustakaan dan perpustakaan tidak hilang begitu saja dari sejarah kehidupan manusia sampai saat ini, karena sejarah kepustakaan dan perpustakaan telah dikuatkan dengan sebuah hasil observasi yang dilakukan oleh peneliti dengan melakukan jejak penelusuraan sejarah keberadaan kepustakaan dan perpustakaan pada masa lampau. Hasil penelusuran jejak sejarah perpustakaan telah jelas ditemukan bekas huruf-huruf yang menunjukan awal adanya kepustakaan dan perpustakaan di dunia Arab yang teletak di atara dua sungai (Mesopotamia) dan wadin nail (Mesir kuno) (Ulyan, 1999: 13).

Terdapat banyak istilah perpustakaan yang digunakan pada masa lampau, karena perpustakaan pada masa lampau tidak seperti pada masa kini yang memiliki sistem administrasi atau manajemen dan tata kepegawaian yang rapi. Orang-orang Sumaria pada masa itu menyebut perpustakaan dengan istilah "Baitul Lahawatul Kabir" karena tempat tersebut digunakan sebagai tempat/gudang yang di dalamnya terdapat papan. Jika di Yunani dikenal dengan istilah "Bibliotheca" yang merujuk adanya perpustakaan, dan istilah tersebut menujuk tempat untuk meletakan buku-buku. Sedangkan di Rumania disebut dengan istilah "Libri" yang menunjukan perpustakaan pribadi dan 
kemudian muncul istilah perpustakaan sebagai tempat belajar. Istilah perpustakaan merupakan istilah baru dalam dunia Arab yang tidak pernah ada hingga pada abad ke-19 akan tetapi untuk layanan-layanan pada perpustakaan pada masa arab telah ada dengan istilah "Dar" dan istilah "khazanah" yang merujuk pada perpustakaan walaupun sistemnya tidak seperti saat ini (Ulyan, 1999: 13).

Keberadaan kepustakaan dan perpustakaan pada masa lampau di negara-negara arab dan eropa sebelum hadirnya islam memang sulit untuk ditentukan kapan waktu koronologis peradaban itu dibangun oleh bangasa-bangsa pada masa itu, akan tetapi keberadaannya dapat diidentifikasi melalui hasil observasi para arkeolog. Sebagaimana penjelasan dari Ulyan (1999: 13-14) dalam bukunya yang berjudul "Perpustakaan dalam Peradaban Islam Arab". ia mengatakan bahwa keberadaan kepustakaan dan perpustakaan pada masa itu ditandai sebagai berikut;

1. Pertama, kemunculan kepustakaan dan perpustakaan diawali huruf-huruf hijaiyah dan angka-angka hingga berbentuk tulisan. Tulisan-tulisan yang muncul tersebut memiliki pengaruh yang sangat besar terhadap peradaban manusia. Karena kemunculan peradaban manusia diawali dengan munculnya tulisan-tulisan atau angka romawi pada masa itu. Tulisan-tulisan itu sebagai simbol dari pengetahuan dan pemikiran manusia pada zamaan tersebut. Zaman masa itu berusaha untuk menuangkan pemikiran dan keilmuan generasinya melalui tulisan dan angkaangka. Jadi tidak mungkin pada masa itu dapat mewariskan peradaban-peradaban yang telah dibangun kepada generasi pada masa sekarang, kecuali melalui tulisan-tulisan dalam bentuk keilmuan dan karya sastra. Dalam menyampaikan tulisan-tulisan tersebut menurut Ulyan (1999: 14) dibagi menjadi tiga bagian; yaitu (1) sebagai gambar (2) sebagai rumus (3) sebagai abjad atau huruf hijaiyah. Kemudian terjadi pergeseran-pergeseran tulisan 
huruf-huruf hijaiyah dari peradaban tersebut ke peradaban Yunani dan Roma sehingga muncul tulisan-tulisan ke dalam bahasa Yunani dan Romawi sebagai bahasa yang resmi.

2. Kedua, munculnya alat metode tulisan yang ada masa itu. Para peneliti menjadikan daun atau pelepah sebagai metode awal penulisan yang kemudian di lapangan berkembang metode dalam penulisan dengan menggunkan alat seperti batu dan lainnya. Setelah perkembanga metode dan alat-alat tersebut, munculah surat menyurat yang dijadikan sebagai alat formalitas dalam pemerintahan Mesir, sehingga alat itu digunakan pada abad pertengahan. Sebelum abad ke-2 SM munculah metode penulisan dengan kulit dan itu digunakan terus menerus sampai kemunculan peradaban cina dan mereka mulai memunculkan media tulis berupa kertas dan media ini mulai berpindah ke wilayah-wilayah lain seperti Samarkand di India, kemudian di Baghdad dan sampai ke masa industri di wilayah Eropa.

3. Ketiga, munculnya percetakan di wilayah Al-Mania pada abda ke-15 dan dari Al-Mania, alat cetak tersebut menyebar sampai ke Eropa dan dunia luas sehingga alat cetak yang pada awalnya yang sederhana sehingga menjadi alat mesin yang mekanik dengan perkembangannya dari segi warna hitam putih dan menjadi warna seperti sekarang ini.

Jika dilihat dari kenyataan di atas, bahwa pada masa itu peradaban Cina jauh lebih maju daripada peradaban Eropa. Misalnya, dalam hal cetak mencetak orang-orang Cina telah menemukan sejenis betuk cetakn berupa cetakan blok denga cara mamahat sebuah aksara pada blok kayu. Blok kayu ini kemudian dioles tinta, kemudian ditekan keras. Teknik tersebut kemudian dikembangkan lagi mejadi tipe gerak yang artinya sebuah aksara yang dapat dipndahkan ke blok lain. Proses semacam ini baru dikenal di Eropa Barat sekitar tahun 1440 M tatkala John Gutenberg dari kota Mainz, Jerman mencetak buku dengan tipe 
cetak gerak. Setiap aksara dilebur ke dalam logam, kemudian dipindahkan ke dasar mesin pres lalu diberi tinta. Kemudian ditaruh kertas di atasnya lalu digulung dengan lempeng pemberat. Sejak penemuan Gutenberg ini (sebenarnya penemuan untuk kawasan Eropa) pembuatan manuskrip yang semula ditulis tangan, kini dapat digandakan dengan mesin cetak. Karena teknik pencetakan yang masih sederhana ini maka hasilnya pun masih sederhana dibandingkan degan cetakan masa kini. Buku yag diterbitkan semasa ini hingga abad ke-16 dikenal dengan nama incunabula (Basuki, 1991: 2).

Jadi dapat disimpulkan bahwa awal kemunculan adanya kepustakaan dan perpustakaan dapat kita lihat dengan tiga indikator yaitu munculnya tulisan-tulisan atau angka yang menandakan awal adanya kepustakaan sebagai karya atau peradaban manusia pada masa lampau, munculnya metode penulisan dengan metode-metode seperti pelepah, daun, dan batubatu sehingga mulai dikenalkan dengan kertas oleh peradaban bangsa cina dan terakhir ditadai dengan munculnya alat cetak di wilayah Al-Mania yang masih manual sehingga lambat laun alat cetak tersebut mulai dikenal di dunia luas sebagai mesin mekanik yang dapat mencetak.

\section{b. Persebaran Perpustakaan Sebelum Islam}

Sejarah mencatat, bahwa terdapat sejumlah perpustakaan yang pernah didirikan oleh manusia sebelum kedatangan islam di Negara arab sebagaimana yang dimaksud dengan tempat diantara dua Sungai yaitu Mesopotamia dan Wadil Nail yaitu:

\section{Perpustakaan di Mesopotamia}

Terdapat banyak pendapat dari para ahli, yang menyatakan bahwa orang-orang Sumaria sebagai awal pencetus dari adanya kata-kata hikmah.. Oleh karena itu, munculah perpustakaan pada masa itu yang ditunjukan dengan karya-karya berupa kata bijak orang-orang terdahulu yang diwariskan ke generasinya. Di sana 
muncul berbagai perpustakaan salah satunya perpustakaan Telloh yang di dalamnya terdapat 30 ribu pelepah atau media tulisan. Di tempat itu juga ditemukan beberapa tempat yang digunakan sebagai tempat menghafal dan terdapat buku-buku tentang keagamaan, sihir, perundang-undangan dan lain-lain (Ulyan, 1999: 15).

Penggalian bekas kerajaan Sumeria menunjukan bahwa bangsa Sumeria sekitar 3000 tahun SM telah menyalin rekening, jadwal kegiatan, dan pengetahuan yang mereka peroleh dalam bentuk lempeng tanah liat (cley tablets). Tulisan yang digunakan masih berupa gambar (pictograph), kemudian ke aksara Sumeria. Kebudayaan Sumeria termasuk kepercayaan, praktik keagamaan, dan tulisan Sumeria. Tulisan Sumeria kemudian diserap oleh Babylonia yang menaklukan Sumeria. Tulisan Sumeria kemudian diubah mejadi tulisan paku (cuneiform) karena mirip paku. Semasa pemerintahan raja Ashurbanipal dari Assyiria (sekitar tahun 688-626) sebelum Masehi) didirikanlah perpustakaan kerajaan di Ibu kota Nineveh, berisi puluhan ribu lempeng tanah liat yang dikumpulkan dari segala penjuru kerajaan. Untuk mecatat koleksi digunakan sistem subjek serta tanda pengenal pada tempat penyimpanan. Banyak dugaan bahwa perpustakaan ini terbuka bagi kawula kerajaan (Basuki, 1991: 22).

Peradaban perpustakaan di Babilonia dan Syiria yang tidak berbeda bentuknya dengan darul makhfuzhat (tempat kata-kata hikmah) dan surat-surat resmi. Dimana makhfuzhat dan sajallat tertata rapi sesuai judul. Diketahui pada masa itu banyak jenis perpustakaan diantaranya:

a. Perpustakaan yang menyimpan buku-buku tentang mantra-mantra, sejarah keagamaan, peraturan suci, dan tata cara ritual keagamaan dan sejarah perjalanan ketuhanan dan lainnya. 
b. Perpustakaan yang berisi tentang kata-kata hikmah dan surat-surat resmi dan ini menjadi salah satu terpeting dari kumpulan buku tentang peribadatan, dan dimana di dalam perpustakaan ini terdapat peraturan dan perundangundangan kerajaan dan para hakim yang menjadi pedoman bagi masyarakat pada masa itu.

c. Perpustakaan yang dijadikan kumpulan surat-surat menyurat yang menjadi pedoman dalam hubungan masyarakat seperti hak kepemilikan dan inipun didasari dari peprustakaan kerajaan dan peradilan.

d. Perpustakaan yang didalamya terdapat surat-menyurat yang berkaitan dengaan mu'amalah (jual beli) dan akad yang bertujuan untuk menjaga kepercayaan kedua belah pihak yang dijadikan sebagai arsip.

e. Perpustakaan sekolah yang di dalamnya terdapat bukubuku ajar yang menjadi rujukan ilmu dan pengetahuan (Ulyan, 1999: 16).

Hal di atas merupakan salah satu bukti bahwa adanya perpustakaan yang berada di wilayah Mesopotamia yang telah ditemukan beberapa simpanan kepustakaan seperti mantramantra, perundang-undangan, sejarah, sihir, ilmu-ilmu, dan buku-buku tentang ketuhanan yang menjadi pedoman kehidupan manusia pada masa itu. Bagian dari perpustakaan yang terkenal yang diketahui sebagai Negara peradaban di antara dua sungai seperti di Lasin, di Telloh dan Perputakaan Nibur dan Perpustakaan Tinu. Adapun perpustakaan Asur Banibal dijadikan sebagai perpustakaan termasyhur dan terbesar diantara perpustakaan yang ada di antara dua Sungai (Mesopotamia dan Wadil Nail).

\section{Perpustakaan Mesir Kuno}

Pada tahun 4000 SM, orang Mesir menggunakan tulisan yang disebut Hieroglyph. Tujuannya untuk memahat pesan 
terakhir di monomen untuk mengungkapkan raja dan tulisan di monomen dan tembok untuk memberikan kesan kepada dunia. Pengembangan peprustakaan di Mesir terjadi pada masa Raja Khufu, Khafre dan Remeses II pda tahun 1250 SM perpustakaan ini memiliki sekitar 20.000 koleksi buku. Perpustakaan Mesir mengalami kemajuan yang pesat berkat penemuan penggunaan rumput papyrus sekitar tahun 1200 SM. Untuk membuat lembar papyrus maka isi batang papyrus dipotong menjadi lembaran tipis, kemudian dibentangkan satu demi satu dan tumpuk demi tumpuk. Kedua lapisan kemudian diikatkan dengan lem, ditekan, diratakan, dan dipukul sehingga permukaannya rata, perpustakaan ini memiliki sekitar 20.000 koleksi buku (Masruri, 2006: 46).

Pada masa itu telah menunjukan adanya perpustakaan di daerah pinggiran nil (Mesir) sejak ribuan tahun. Orang-orang mesir kuno mengetahui tentang penulisan tersebut sejak $5000 \mathrm{SM}$ yang mana dapat dibuktikan dengan berbagai macam cara seperti ornament, gambar pada spink, piramida dan sebagainya. Semangat orang Mesir dapat dilihat dari tulis menulis yang dilakukan berupa karya karya sastra atau kesenian yang mereka tulis dan apabila dilihat dari sudut pandang ini bahwa cara-cara penulisan tersebut sangat bermacam-macam bagi orang mesir kuno sebelum adanya alat atau media penyalinan. (Ulyan, 1999: 16-17)

Perpustakaan di Mesir sudah ada sejak 1000 tahun lalu yang ditemukan karya-karya yang dijadikan sebagai pembelajaran. Perpustakaan pada masa ini dibagi menjadi tiga bagian yaitu:

a. Perpustakaan untuk kuil di dalamnya terdapat karya yang berkaitan dengan urusan agama dan kejadian-kejadian sejarah yang dinisbatkan pada berita-berita ketuhanan.

b. Perpustakaan pemerintah atau kerajaan yang terdiri dari surat-menyurat raja dan hal-hal yang berkaitan dengan 
peraturan perundang-undangan dan segala sesuatu yang berkaitan dengan aturan atau hukum.

c. Perpustakaan khusus bagi para ilmuan yang fokus terhadap disipli ilmu. Kemudian disitu juga terdapat keilmuan atau lembaran penelitian seseorang dan cerita tentang perjalanan seseorang (Biografi) (Ulyan, 1999: 17).

\section{Perpustakaan Yunani Kuno}

Sejarah perbukuan dan perpustakaan pada masa Yunani kuno masih belum jelas karena berada pada sebuah lembah hal ini menjadi faktor rusaknya dari bekas dari tinta pada buku-buku tersebut. Di wilayah tersebut dapat dipercaya sebagai permulaan munculnya tulisan pada masa pemerintahan Humirus. Perpustakaan Yunani telah muncul pada abad ke-5 M, akan tetapi sebelumnya belum ada perpustakaan kecuali pada masa Aristoteles dan Plato yang sekian lama semakin tergerus sehingga pada abad ke-5 adanya upaya penyelematan karya-karya mereka di Perpustakaan Iskandriyah yang menjadi pusat pada masa itu. Perpustakan pada masa itu dibagi menjadi 2 yaitu perpustakaan besar (masa patolomus pertama) dan perustakaan kecil (Ulyan, 1999: 18).

Peradaban Yunani mengenal tulisan Mycena sekitar 1500 SM, kemudian tulisan tersebut lenyap. Sebagai penggantinya, orang Yunani menggunakan 22 aksara temuan orang Phoenicia, kemudian dikembangkan menjadi 26 aksara seperti yang kita kenal sekarang. Perkembangan perpustakaan Yunani mencapai puncaknya pada masa Abad Hellenisme yang ditandai dengan penyebaran ajaran dan kebudayaan Yunani. Perpustakaan yang terkenal adalah perpustakaan Alexandria yang memiliki 700.000 gulungan koleksi pada abad pertama SM yang koleksinya adalah teks Yunani dan manuskrip segala bahasa dari semua penjuru dunia. Semua gulungan papirus ini disunting, disusun menurut bentuknya, dan diberi catatan untuk disusun menjadi sebuah 
bibliografi sastra Yunani yang semuanya itu disusun oleh semua pustakawan perpustakaan Alexandria yang mereka adalah ilmuwan ulung yang ahli dalam bidangnya (Basuki, 1991: 23).

Perpustakaan Iskandariyah menyimpan karya-karya tokohtokoh besar filosof pada masa itu. Terdapat sebuah riwayat yang menyatakan bahwa keberadaan perpustakaan Iskandariyah yang dijadikan sebagai pusat penyimpanan karya-karya para tokoh dan filosof namun kemegahan perpustakaan Iskandariyah mengalami kehancuran dan pembakaran perpustakaan.

Sewaktu bangsa Arab menaklukkan Mesir pada tahun $\underline{640}$ SM, perpustakaan Alexandria kemungkinan sudah tidak ada. Para cendikiawan masih berdebat tentang bagaimana dan kapan tepatnya perpustakaan itu lenyap. Ada yang mengatakan bahwa banyak isinya mungkin hilang sewaktu Julius Caesar membakar sebagian kota itu pada tahun 47 SM. Apa pun penyebabnya, lenyapnya perpustakaan itu menyebabkan hilangnya segudang pengetahuan. Lenyap pula ratusan karya penulis drama Yunani serta catatan tentang 500 tahun pertama sejarah Yunani kecuali beberapa karya Herodotus, Tusidides dan Xenopon. (Parson, 1959: https://id.wikipedia.org/wiki/Perpustakaan_Iskandariyah).

\section{Perpustakaan Romawi Kuno}

Perkembangan perpustakaan di Romawi kuno berasal dari sistem pendidikan-pendidikan di Roma, sehingga dari pendidikan itu munculah perpustakaan seperti perpustakaan rumahan/pribadi dan ini yang menghiasi peradaban-peradaban di Roma pada masa itu. Kemudian dari perpustakan kecil atau pribadi tersebut munculah para ilmuan dan peneliti. Sedangkan perpustakaan umum dan perpustakaan kerajaan mucul pada fase akhir sampai pada abad ke-2 sudah terdapat dua puluh enam perpustakaan dalam setahun. Hal ini sampai para pendeta pada masa itu memfasilitasi tempat ibadah dengan perpustakaan. 
Perpustakaan pada peradaban Roma memiliki peranan peting dalam menjaga buku-buku kuno. Akan tetapi perpustakaan pada masa ini belum bisa menyamai dengan perpustakaan yang ada pada masa Yunani yang dapat mencetak para ahli ilmu seperti Aristoles dan Plato. Sehingga pada masa raja Embritur mulai muncul peradaban-peradaban keilmuan Roma yang memberikan pengaruh terhadap peradaban selanjutnya (Ulyan, 1999: 19).

Perkembangan perpustakaan pribadi yang ada di wilayah Roma merupakan sebuah kemajuan yang diakibatkan oleh banyaknya buku-buku rampasan perang yang diperoleh tentara pada masa itu. Perpustakaan pribadi yang menjadi penyimpanan buku-buku berbentuk Codex/karya kuno tersebut yang lambat laun menjadi perpustakaan yang terbuka untuk umum.

Perpustakaan-perpustakaan di Roma ini mulai mengalami kemunduran seiring dengan kemunduran kerajaan Roma sehingga yang tersisa adalah perpustakaan biara. Antara abad Ke-3 dan abad ke-6 Masehi kota Alexandria sering mengalami kerusuhan, pertikaian dan peperangan antara orang Yahudi, orang Kristen dan agama lain, sehingga tak terhitung banyaknya naskah naskah kuno yang musnah. Hal ini serupa dengan kejadian pada perpustakaan-perpustakaan di Baghdad ketika penyerbuan Genghis Khan dari bangsa Mongol ke Timur Tengah, bahkan sama ketika perpustakaan Bagdad mengalami penjarahan kembali ketika penyerbuan Amerika Serikat pada tahun 2003 lalu (Masruri, 2006: 47).

\section{Perpustakaan pada Masa Pertengahan di Eropa}

Masa pemerintahan Embritur Romawi sebelum Barbar sebagaimana yang telah diulas di atas sangat memberikan dampak pemikiran terhadap peradaban di era pertengahan. Dimana pada masa itu masyarakat menjaga karya sastra klasik Yunani dan Roma dan intinya pada zaman ini menjadikan daerah-daerah 
sebagai tempat pusat pendidikan dan sebagai tempat untuk memelihara buku-buku keagamaan.

Setelah kedatangan Syarloman pada tahun 768-814 M mulai dihargai keberadaan perpustakaan sebagai suatu peradaban yang mempengaruhi pusat-pusat pendidikan pada masa itu. Peningkatan peradaban pada masa ini ditandai dengan adanya teknologi atau penggunaan alat-alat tulis seperti kertas kering dan pulpen dari bulu burung dengan menggunakan tinta yang berwarna. Kemudian pada masa itu juga sudah dilakukan pembuatan lemari yang digunakan untuk menjadi pembatas karya-karya yang tersimpan sesuai dengan klasifikasinya, misalnya sesuai dengan sejarahnya (Ulyan, 1999: 20).

Selanjutnya pada masa ini berkaitan dengan penyampain proses pendidikan dimana pada masa ini terdapat sebuah balai pendidikan yang difasilitasi oleh gereja yang disampaikan oleh orang gereja, dan tempat ini kebanyakan berasal dari putra-putra raja dan orang-orang kaya. Dari awal pendidikan gereja inilah kemudian muncul pada abad pertegahan ini sebuah Universitas seperti Cambrig University, Oxford University, dan Universitas Paris (Ulyan, 1999: 20).

Perpustakaan-perpustakaan tersebut memberikan kontribusi yang sangat besar dalam kepustakaan pada abad ini, kontribusi tersebut tidak hanya pada aspek pendidikan seperti menghafal dan menulis akan tetapi memberikan sebuah motivasi untuk melakukan sebuah review ulang terhadap naskah-naskah kuno yang dihasilkan oleh para ilmuan sebelumnya. Sehingga dari kegiatan ini akan muncul penulis atau pengarang selanjutnya. Kegiatan yang dilakukan mahasiswa dengan mengulas ulang terhadap naskah-naskah kuno yang dihasilkan para ilmuan terdahulu, maka menutut perpustakaan untuk melakukan sebuah penertiban yang semakin kompleks dengan sistem 
pengklasifikasian karya-karya tersebut berdasarkan judulnnya (Ulyan, 1999: 20).

Berdasarkan ulasan-ulasan di atas, jelas bahwa sejarah perpustakaan pada masa klasik hingga pada abad pertengahan memberikan kontribusi keilmuan bagi peradaban manusia khisusnya wilayah-wilayah Eropa yang sekarang dapat kita lihat telah menjadi sebuah kawasan pusat pendidikan barat, industri, teknologi hingga perdangangan dunia yang semua itu tidak terlepas dari sejarah kepustakaan dan perpustakaan pada masa lampau.

\section{Kesimpulan}

Berdasarkan pemaparan di atas, penulis dapat menyimpulkan bahwa sejarah perpustakaan sebelum islam mengalami perkembangan yang cukup dinamis, walaupun memang sulit untuk memastikan kapan secara kronologis peradaban itu dibangun oleh masyarakat arab sebelum islam. Hal tersebut dapat dilihat dari adanya kepustakaan dan perpustakaan yang ada di wilayan Mesopotamia yang pada awalnya orang Sumaria sebagai awal pencetus tulis menulis dan terdapat juga kepustakaan dan Perpustakaan Wadil Nail yaitu perpustakan Mesir kuno, dimana orang-orang mesir yang pada awalnya menggunakan tulisan yang disebut Hieroglyph.

Keberadaan kepustakaan dan Perpustakaan pada masa itu memang telah memberikan sebuah nuansa tersendiri dalam membangun sebuah peradaban manusia dan ilmu pengetahuan, karena hanya dengan ini mereka dapat mewarisi pesan-pesan dan keilmuan kepada generasi-generasi penerus mereka untuk tetap membangun peradaban yang berkelanjutan hingga saat ini.

Keberlanjutan peradaban perpustakaan sebelum islam berdampak pada kemajuan-kemajuan bangsa Eropa dalam bidang ilmu pengetahuan, hal ini dapat dilihat dari adanya pengadopsian ilmu-ilmu pada masa Yunani kuno dan Roma 
sehingga pada abad pertengahan perpustakaan yang ada memberikan kontribusi yang sangat besar yang dapat dilihat dari beridirinya Universitas-universitas di Eropa.

\section{Daftar Pustaka}

Basuki, Sulistyo. (1991). Pengantar Ilmu Perpustakaan dan Informasi. Yogyakarta: PT Gramedia Pustaka Utama.

Masruri, Anis, dkk. (2006). Sejarah Perpustakaan Islam. Yogyakarta: Fakultas Adab UIN Sunan Kalijaga.

Nurhadi, Muljani. (1983) Sejarah Perpustakaan dan Perkembangannya di Indonesia. Yogyakarta: Andi Offset.

Parsons, Edward. The Alexandrian Library. London. (1952).dalam https://id.wikipedia.org/wiki/Perpustakaan_Iskandariyah diakses pada tanggal 22 November 2015 pukul 10.00 wib.

Sutarno NS. (2006). Perpustakaan dan Masyarakat. Jakarta: Sagung Seto.

Ulyan, Rubhi Mustofa. (1420 H/1999 M). Perpustakaan dalam Peradaban Islam Arab. Jordania: Dar Safa. 